\title{
Penerapan Metode Inquiri Terpimpin dalam Meningkatkan Prestasi Belajar Siswa Pokok Bahasan Hidup Tenang dengan Kejujuran, Amanah dan Istiqomah Kelas VII/D SMPN 2 Kota Bima Tahun Pelajaran 2019/2020
}

\author{
Siti Nurminhayati \\ ${ }^{1}$ Sekolah Menegah Pertama Negeri 02 Kota Bima Nusa Tenggara Barat \\ Email: nurminhayatismp02@gmail.com
}

\begin{abstract}
ABSTRAK
Penelitian ini bertujuan untuk meningkatkan prestasi siswa kelas VII/D di SMPN 2 Kota Bima pada materi pembelajaran hidup tenang dengan kejujuran, amanah dan istiqomah melalui penerapan metode pembelajaran Inquiri Terpimpin. Jenis penelitian yang digunakan adalah penelitian tindakan kelas yang dilakukan dengan menggunakan siklus, dimana setiap siklus terdiri dari 3 pertemuan yang mana 2 pertemuan untuk proses pembelajaran dan 1 pertemuan untuk evaluasi. Sampel dalam penelitian ini adalah siswa kelas VII/D SMPN 2 Kota Bima yang berjumlah 32 orang. Data ketuntasan prestasi belajar siswa dikumpulkan melalui tes evaluasi sedangkan data ketuntasan aktivitas siswa dan guru dikumpulkan melalui lembar observasi. Dari hasil penelitian diperoleh bahwa jumlah skor aktivitas siswa dalam 2 siklus selalu mengalami peningkatan. Pada siklus I skor aktivitas berturut-turut pertemuan pertama $47 \%$ dan pertemuan kedua $60 \%$ dengan kategori aktif sedangkan pada siklus II skor aktivitas siswa pertemuan pertama $73 \%$ dan pertemuan kedua $87 \%$ dengan kategori sangat aktif. Selain itu, prosentase ketuntasan prestasi belajar siswa dalam 2 siklus berturut-turut siklus I adalah $72 \%$ dan siklus II adalah $88 \%$. Ketuntasan prestasi belajar siswa dalam 2 siklus selalu meningkat, hal ini disebabkan karena siswa aktif menemukan sendiri konsep-konsep yang ada dalam LKS sehingga materi yang ditemukan akan lama diingat. Dari hasil keseluruhan penelitian ini dapat disimpulkan bahwa penerapan metode pembelajaran Inquiri Terpimpin dapat meningkatkan prestasi dan aktivitas belajar siswa kelas VII/D di SMPN 2 Kota Bima pada materi pembelajaran hidup tenang dengan kejujuran, amanah dan istiqomah.
\end{abstract}

Kata Kunci : Inquiri terpimpin, prestasi belajar

\section{ABSTRACT}

This study aims to improve the achievements of VII/D grade students at SMPN 2 City Bima on learning materials for a quiet life with honesty, trustworthiness and istiqomah through the application of Guided Inquiry learning methods. This type of research is a classroom action research conducted using cycles, where each cycle consists of 3 meetings where 2 meetings for the learning process and 1 meeting for evaluation. The sample in this study were students of class VII/D SMPN 2 City of Bima, amounting to 32 people. The completeness data of students' learning achievement is collected through evaluation tests while the completeness data of student and teacher activities is collected through observation sheets. From the results of the study it was found that the total score of student activity in 2 cycles always increased. In the first cycle the activity score of the first meeting was $47 \%$ and the second meeting was $60 \%$ with the active category while in the second cycle the activity score of the first meeting students was $73 \%$ and the second meeting was $87 \%$ with the very active category. In addition, the percentage of completeness of student achievement in 2 consecutive cycles in the first cycle was $72 \%$ and in the second cycle was $88 \%$. Completeness of student achievement in 2 cycles always increases, this is because students actively find their own concepts in the worksheet so that the material found will be long remembered. From the overall results of this study it can be concluded that the application of Guided Inquiry learning methods can improve the achievement and learning activities of VII/D grade students at SMPN 2 City Bima on learning materials live quietly with honesty, trustworthiness and istiqomah

Keywords: Guided inquiry, learning achievement 


\section{PENDAHULUAN}

Pendidikan saat ini merupakan peranan yang sangat penting dalam menyiapkan sumber daya manusia yang berkualitas tinggi untuk membangun peradaban bangsa. Salah satu kualitas yang dituntut keberadaannya dalam diri anak bangsa adalah kemampuannya memahami pendidikan Agama melaluli Pendidikan Agama Islam dan Budi pekerti yang merupakan salah satu mata pelajaran penting yang ada pada berbagai tingkat pendidikan mulai dari TK, SMP, SMA, sampai perguruaan tinggi. Berdasarkan hasil Observasi peneliti pada tiap tahun pelajaran, banyak siswa yang kurang bersemangat dalam mengikuti pembelajaran Pendidikan Agama Islam dan Budi Pekerti yang dimana peneliti sebagai guru mata pelajaran kelas VII SMPN 2 Kota Bima ingin mencoba merubah kegiatan proses pembelajaran selama ini dengan menggunakan metode atau model pembelajaran yang dapat merubah semangat siswa untuk mengikuti pembelajaran, karena selama ini pengajaran masih berpusat pada guru, sehingga siswa kurang aktif dalam proses pembelajaran, kurang termotivasi dalam belajar Pendidikan Agama Islam dan Budi pekerti, dan siswa kurang paham terhadap konsep Pendidikan Agama Islam dan Budi pekerti. Berdasarkan hasil observasi tiap tahun, maka peneliti menetapkan kelas penelitian pada kelas VII/D SMPN 2 Kota Bima sebagai obyek penelitian yang berjumlah 32 orang siswa, dimana hampir $65 \%$ siswa di kelas VII/D mengatakan pelajaran Pendidikan Agama Islam dan Budi pekerti merupakan pelajaran yang membosankan untuk diikuti dan terlalu monoton. Hal ini dikarenakan pada saat melakukan proses belajar mengajar pada umumnya guru langsung mulai memaparkan materi kemudian menerangkan dan selanjutnya mengevaluasi siswa dengan cara memberi pertanyaan.

Faktor-faktor tersebut di atas, seharusnya bisa diatasi dengan menggunakan model pembelajaran yang dapat melibatkan keaktifan siswa dalam proses pembelajaran PAI dan Budi Pekerti. Oleh karena itu, hendaknya setiap pendidik terlebih dahulu dapat mempertimbangkan model apa yang tepat digunakan sehingga siswa lebih aktif dalam kegiatan pembelajaran yang pada akhirnya dapat meningkatkan hasil belajar siswa. Salah satu model pembelajaran yang dapat digunakan untuk meningkatkan aktivitas dan hasil belajar siswa adalah model pembelajaran inkuiri terbimbing, dimana proses pembelajaran berorientasi pada siswa yang dapat menstimulus siswa untuk aktif dalam kegiatan belajar mengajar. Gulo (2008: 84) bahwa inkuiri terbimbing adalah model pembelajaran yang melibatkan kemampuan siswa secara maksimal untuk menemukan dan menyelidiki suatu permasalahan dalam pembelajaran. 
Pembelajaran inkuiri menekankan kepada proses mencari dan menemukan. Materi pelajaran tidak diberikan secara langsung kepada siswa tetapi proses belajar mengajar tetap dibawah pengawasan dan bimbingan/petunjuk dari guru. Guru sebagai fasilitator dan motivator bagi siswa dalam melangsungkan proses pembelajaran dan diharapkan siswa dapat memahami konsep materi yang telah diajarkan sehingga menimbulkan rasa senang terhadap pembelajaran. Menurut Basyiruddin dalam Istarani (2012:132) mengatakan bahwa inkuiri adalah suatu cara penyampaian pelajaran dengan penelaahan sesuatu yang bersifat mencari secara kritis, analitis, dan argumentatif (ilmiah) dengan menggunakan langkah-langkah tertentu menuju suatu kesimpulan. Hosnan (2014: 340) menyatakan bahwa inkuiri merupakan bagian inti dari pembelajaran kontekstual, proses menemukan merupakan yang paling penting dalam pembelajaran.

Hanafiah (2009:77), "Inkuiri terbimbing, yaitu pelaksanaaan inkuiri dilakukan atas petunjuk dari guru. keduanya, dimulai dari pertanyaan inti, guru menunjukkan berbagai pertanyaan yang melacak, dengan tujuan untuk mengarahkan peserta didik ke titik kesimpulan yang diharapkan. Selanjutnya, siswa melakukan percobaan untuk membuktikan pendapat yang dikemukakannya".

\section{METODE PENELITIAN}

Penelitian ini merupakan penelitian tindakan kelas (PTK) dengan menerapkan model pembelajaran inkuiri terbimbing. Penelitian ini dilaksanakan di kelas VII/D SMPN 2 Kota Bima, yang berlokasi di Jalan Bougenvile Kelurahan Na;e kota Bima pada semester ganjil tahun ajaran 2019/2020, Subjek dalam penelitian ini adalah seluruh siswa kelas VII SMPN 2 Kota Bima yang berjumlah 32 orang siswa. Sedangkan yang menjadi objek dalam penelitian ini adalah hasil belajar siswa kelas VII/D SMPN 2 Kota Bima, pada materi hidup tenang dengan kejujuran, amanah dan istiqomah dengan menerapkan model pembelajaran inkuiri terbimbing.

Penelitian tindakan kelas secara garis besar terdapat empat tahapan yang lazim dilalui, yaitu perencanaan, pelaksanaan tindakan, observasi/evaluasi dan refleksi. 
Adapun tahapan pada penelitian tindakan kelas yang dilakukan dari awal hingga akhir dapat dilihat pada gambar berikut :

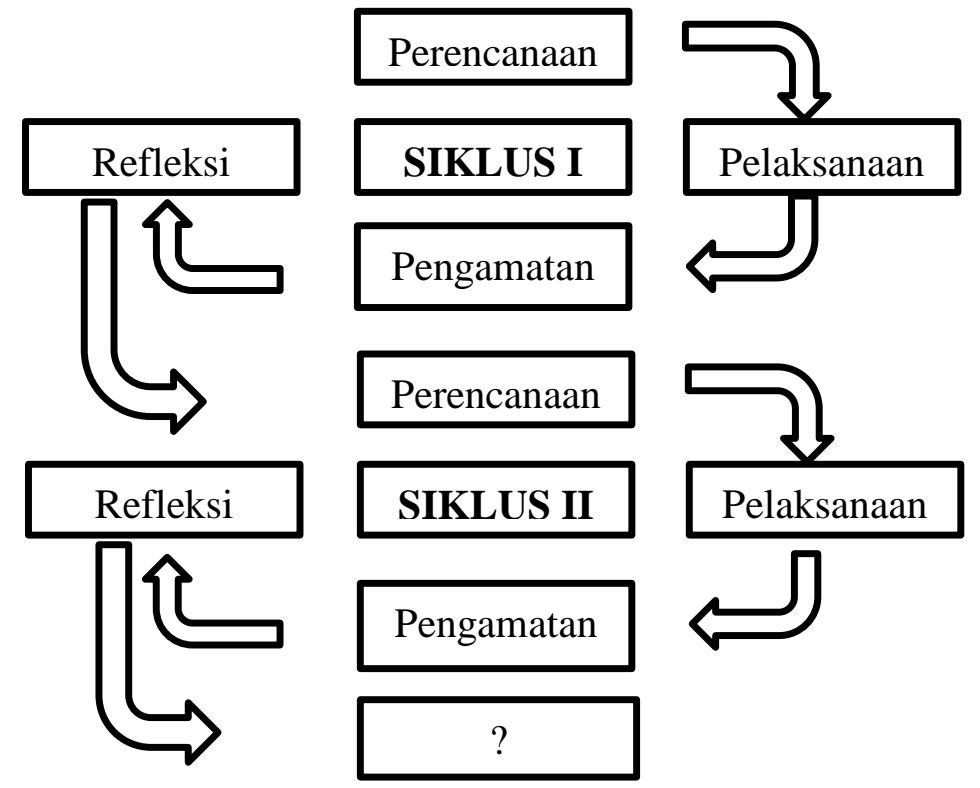

Gambar 1. Model Penelitian Tindakan

(Suharsimi, 2010:137)

Data yang diambil berupa hasil belajar siswa, aktivitas guru dan siswa selama pembelajaran, kemampuan guru dalam mengelola pembelajaran dan tanggapan siswa terhadap model pembelajaran yang digunakan.

Instrumen yang digunakan dalam penelitian ini meliputi test (test tertulis dalam bentuk soal dan soal pilihan ganda), lembar pengamatan/observasi.

Teknik analisis data dalam penelitian ini yaitu menganalisis aktivitas siswa, menganalisis aktivitas Guru serta anilisis tes hasil belajar, adapun teknik analisis data yang digunakan sebagai berikut :

1. Data Hasil Observasi Aktivitas Siswa

Data hasil observasi siswa dianalisis dengan langkah-langkah sebagai berikut:

a. Menentukan skor yang diperoleh siswa

Skor setiap individu tergantung banyaknya perilaku yang dilakukan oleh siswa dari sejumlah indikator yang diamati.

Tabel 1. Penentuan skor siswa

\begin{tabular}{|c|c|}
\hline Banyak Siswa & Skor Deskriptor \\
\hline $76 \%-100 \%$ melakukan deskriptor & 4 \\
\hline $51 \%-75 \%$ melakukan deskriptor & 3 \\
\hline
\end{tabular}




\begin{tabular}{|l|l|}
\hline $26 \%-50 \%$ melakukan deskriptor & 2 \\
\hline $0 \%-25 \%$ melakukan deskriptor & 1 \\
\hline
\end{tabular}

(Nurkancana, dalam Multazan, 2011:44).

b. Menghitung skor aktivitas siswa dengan rumus:

$$
A s=\frac{\sum X}{i}
$$

Dengan:

As $=$ Rata-rata skor aktivitas siswa

$\mathrm{X}=$ Skor setiap deskriptor aktivitas siswa

$i=$ Banyaknya deskriptor

c. Menentukan Mean Ideal dan Standar Deviasi Ideal.

$$
\begin{aligned}
\mathrm{MI} & =\frac{1}{2} \times(\text { sekorterendah }+ \text { sekortertinggi }) \\
\mathrm{SDI} & =\frac{1}{3} \times \mathrm{MI} \text { atau } \\
\mathrm{SDI} & =\frac{1}{6} \times(\text { sekorterendah }+ \text { sekortertinggi })
\end{aligned}
$$

Keterangan:

MI : Mean Ideal

SDI : Standar Deviasi Ideal

d. Menentukan kategori aktivitas belajar siswa

Kategori aktivitas belajar siswa adalah sebagai berikut :

Tabel 2. Kategori aktivitas siswa

\begin{tabular}{|l|l|}
\hline \multicolumn{1}{|c|}{ Nilai } & \multicolumn{1}{|c|}{ Kategori } \\
\hline As $\geq \mathrm{MI}+1,5 \mathrm{SDI}$ & Sangat Tinggi \\
$\mathrm{MI}+0,5 \mathrm{SDI} \leq \mathrm{As}<\mathrm{MI}+1,5 \mathrm{SDI}$ & Tinggi \\
$\mathrm{MI}-0,5 \mathrm{SDI} \leq \mathrm{As}<\mathrm{MI}+0,5 \mathrm{SDI}$ & Cukup \\
$\mathrm{MI}-1,5 \mathrm{SDI} \leq \mathrm{As}<\mathrm{MI}-0,5 \mathrm{SDI}$ & Rendah \\
As $<\mathrm{MI}-1,5 \mathrm{SDI}$ & Sangat Rendah \\
\hline
\end{tabular}

Keterangan As = Rata-rata skor aktivitas siswa (Nurkancana dalam Multazan,2011:44). 
2. Data Hasil Observasi Aktivitas Guru

Data hasil observasi aktivitas guru selama pembelajaran berlangsung dianalisis dengan langkah-langkah sebagai berikut :

a. Menentukan skor yang diperoleh

Skor guru ditetukan dari banyaknya perilaku yang dilakukan oleh guru dari sejumlah indikator yang diamati.

Tabel 3. Penentuan skor guru

\begin{tabular}{|c|l|}
\hline $\begin{array}{c}\text { Skor } \\
\text { Indikator }\end{array}$ & \multicolumn{1}{c|}{ Kriteria } \\
\hline 4 & 3 deskriptor yang nampak \\
\hline 3 & 2 deskriptor yang nampak \\
\hline 2 & 1 deskriptor yang nampak \\
\hline 1 & tidak ada deskriptor yang nampak \\
\hline
\end{tabular}

b. Menghitung skor aktivitas guru dengan rumus:

$$
A g=\frac{\sum X}{i} \text {. }
$$

Dengan:

$\mathrm{Ag}=$ Rata-rata skor aktivitas guru

$\mathrm{X}=$ Skor setiap indikator aktivitas guru

$i=$ Banyaknya indikator

c. Menentukan skor maksimal ideal dan standar deviasi ideal

$\mathrm{MI}=\frac{1}{2} \times($ sekorterendah + sekortertinggi $)$

$\mathrm{SDI}=\frac{1}{3} \times \mathrm{MI}$ atau

$\mathrm{SDI}=\frac{1}{6} \times($ sekorterendah + sekortertinggi $)$

Keterangan:

MI : Mean Ideal

SDI : Standar Deviasi Ideal

d. Menentukan kategori aktiviatas guru

Kategori aktivitas guru adalah sebagai berikut: 
Tabel 4. Kategori kegiatan guru

\begin{tabular}{|l|l|}
\hline \multicolumn{1}{|c|}{ Nilai } & \multicolumn{1}{|c|}{ Kategori } \\
\hline $\mathrm{Ag} \geq \mathrm{MI}+1,5 \mathrm{SDI}$ & Sangat tinggi \\
$\mathrm{MI}+0,5 \mathrm{SDI} \leq \mathrm{Ag}<\mathrm{MI}+1,5 \mathrm{SDI}$ & Tinggi \\
$\mathrm{MI}-0,5 \mathrm{SDI} \leq \mathrm{Ag}<\mathrm{MI}+0,5 \mathrm{SDI}$ & Sedang \\
$\mathrm{MI}-1,5 \mathrm{SDI} \leq \mathrm{Ag}<\mathrm{MI}-0,5 \mathrm{SDI}$ & Rendah \\
$\mathrm{Ag}<\mathrm{MI}-1,5 \mathrm{SDI}$ & Sangat rendah \\
\hline
\end{tabular}

(Nurkancana dalam Multazan,2011:45).

3. Data Tes Hasil Belajar

Setelah memporeh data tes hasil belajar, maka data tersebut dianalisis dengan mancari ketuntasan belajar dan daya serap, kemudian dianalisis secara kuantitatif.

a. Ketuntasan Individu

Setiap siswa dalam proses belajar mengajar dikatakan tuntas apabila memperoleh nilai $\geq 70$. Nilai ketuntasan minimal sebesar 70 dipilih karena sesuai dengan kemampuan individu, hal ini sesuai dengan standar ketuntasan belajar siswa pada di SMPN 2 Kota Bima.

b. Ketuntasan Klasikal

Data tes hasil belajar proses pembelajaran dianalisis dengan menggunakan analisis ketuntasan hasil belajar secara klasikal minimal $85 \%$ dari jumlah siswa yang memperoleh nilai $\geq 70$. Dengan rumus ketuntasan belajar klasikal adalah:

$$
K K=\frac{X}{Z} \times 100 \%
$$

Dimana:

$\mathrm{KK}=$ Ketuntasan klasikal

$\mathrm{X}=$ Banyaknya siswa yang memperoleh nilai $\geq 70$

$\mathrm{Z}=$ Banyaknya siswa yang mengikuti tes

Ketuntasan belajar klasikal tercapai jika $\geq 85 \%$ siswa memperoleh skor minimal 70 yang akan terlihat pada hasil evaluasi tiap-tiap siklus.

\section{HASIL DAN PEMBAHASAN}

Berdasarkan hasil pengamatan selama pelaksanaan pembelajaran oleh Observer pada siklus II, maka tindakan dalam siklus diberhentikan karena hasil belajar sudah maksimal dan sebagian besar siswa telah berhasil menuntaskan belajarnya baik secara individual maupun secara klasikal, serta guru telah mampu menerapkan pembelajaran inkuiri terbimbing dengan sangat baik. 
Data hasil penelitian yang diperoleh di kelas VII/D SMPN 2 Kota Bima tahun ajaran 2019/2020 selama dua siklus dan pada setiap pertemuan diamati oleh pengamat /observer. Persentase ketuntasan klasikal siklus I sebesar 72\%. Pada siklus kedua, nilai ketuntasan klasikal semakin meningkat, sehingga persentase ketuntasan klasikal sebesar 88\%. Aktivitas guru dan siswa yang diamati dengan menggunakan instrumen mulai dari siklus 1 sampai dengan siklus 2 secara keseluruhan juga meningkat, dimana pada siklus I untuk Aktivitas siswa pertemuan pertama $60 \%$ dan kedua $80 \%$ masih terdapat beberapa aktivitas siswa yang belum sesuai dengan instrument observasi yang ditetapkan, pada siklus II untuk intrumen observasi siswanya semakin terpenuhi dengan adanya perubahan nilai persentase yang semakin meningkat dari pertemuan ke pertemuan terutama siklus II pertemuan I sebesar $87 \%$ dan pertemuan kedua 93\%. Peningkatan keterampilan guru dalam mengelola pembelajaran dengan menerapkan model pembelajaran inkuiri terbimbing dari siklus pertama hingga siklus kedua. Pada siklus I pertemuan pertama skor rata-rata 1,8 dan pertemuan kedua skor rata-rata 2,4 dengan kategori kurang baik, pada siklus II pertemuan pertama skor rata-rata 2,6 dan pertemuan kedua skor rata-rata 2,8 dengan kategori sangat baik. Aktifitas Guru dan siswa dalam kegiatan pembelajaran mata pelajaran Pendidikan Agama Islam dan Budi pekerti pokok bahasan hidup tenang dengan kejujuran, amanah dan istiqomah pada kelas VII/D SMPN 2 Kota Bima Tahun pelajaran 2019/2020 dengan menggunakan metode Inquiri Terbimbing dapat meningkatkan prestasi belajar siswa.

\section{KESIMPULAN}

Berdasarkan hasil analisis data pada penelitian tindakan kelas yang telah dilakukan selama 2 siklus terlihat adanya perubahan yang merupakan hasil penelitian dalam rangka meningkatkan hasil belajar Pendidikan Agama Islam dan Budi pekerti dengan menerapkan model pembelajaran Inkuiri terbimbing. Maka kesimpulan yang diperoleh dari kegiatan tersebut adalah sebagai berikut:

Penerapan model pembelajaran inkuiri terbimbing terbukti dapat meningkatkan hasil belajar siswa baik ketuntasan secara individual maupun secara klasikal.

Aktivitas guru dan siswa selalu mengalami perbaikan setiap siklusnya, Hal ini menunjukkan bahwa pembelajaran yang dilakukan sudah berjalan sesuai dengan yang terdapat pada RPP.

Keterampilan guru dalam mengelola pembelajaran dengan menerapkan model pembelajaran inkuiri terbimbing juga mengalami peningkatan setiap siklusnya. 
Respon yang diberikan siswa terhadap pembelajaran yang diterapkan selama dua siklus adalah positif. Ini menunjukkan bahwa siswa senang, berminat dan tertarik untuk mengikuti pembelajaran dengan diterapkannya model pembelajaran inkuiri terbimbing.

\section{DAFTAR PUSTAKA}

Agustin Dan Dewi Sri, Dkk. 2017. Pendidikan Agama Islam Dan Budi Pekerti. Surakarta: CV Surya Badra.

Arief, Armai. 2002. Pengantar Ilmu Dan Metodologi Pendidikan Islam. Jakarta: Ciputat Pres.

Arikunto, Suharsimi, Dkk. 2007. Penelitian Tindakan Kelas. Jakarta: Ikrar Mandiri Abadi.

Basrowi Dan Suwandi. 2008. Memahami Penelitian Tindakan Kelas. Jakarta:Rineka Cipta.

Kementrian Agama Republik Indonesia. 2014. pendidikan agama islam dan budi pekerti. Jakarta: Kementrian pendidikan dan kebudayaan.

Luthfiah, Zeni Dan Muh. Farhan Mujahidin, Dkk. 2011. Pendidikan Agama Islam. Surakarta: Yuma Pustaka.

Majid, Abdul. 2014. Belajar Dan Pembelajaran Pendidikan Agama Islam. Bandung: Pt.Remaja Rosdakarya.

Rohman, Arif. 2013. Memahami Ilmu Pendidikan. Yogyakarta: Cv Aswaja Pressindo. Semiawan, Conny, Dkk. 2001. Pendekatan Ketrampilan Proses. Jakarta: Gramedia.

Suyadi. 2014. Panduan Penelitian Tindakan Kelas. Yogyakarta: Diva Press.

Syah, Muhibbin. 2010. Psikologi Belajar. Jakarta: Rajawali Pers.

Arikunto, Suharsimi. 2009. Penelitian Tindakan Kelas. Jakarta: Bumi Aksara. Gulo, W. 2008. Strategi Belajar Mengajar. Jakarta: PT. Grasindo.

Hermawan, Hendy. 2007. Teori Belajar dan Motivasi. Bandung: Citra Praya.

Johar, Rahmah, dkk. 2006. Strategi Belajar Mengajar. Banda Aceh: Universitas Syiah Kuala.

Jufri, Wahab. 2013. Belajar dan Pembelajaran SAINS. Bandung: Pustaka Reka Cipta.

Kurniawan, A.D. 2013. Metode Inkuiri Terbimbing dalam Pembuatan Media Pembelajaran Biologi untuk Meningkatkan Pemahaman Konsep dan Kreativitas Siswa SMP. Jurnal Pendidikan IPA Indonesia (JPII) 2 (1) (2013) 8-11.

Kunti, Mia. 2014. "Perbandingan Hasil Belajar siswa Menggunakan Model Pembelajaran Problem Based Instruction (PBI) Berbasis Komputer dengan Pendekatan Konvensional pada Siswa SMPN 18 Banda Aceh”. Skripsi tidak diterbitkan. Darussalam: Universitas Syiah Kuala. 
Mulyasa, Enco. 2012. Menjadi Guru Profesional Menciptakan Pembelajaran Kreatif dan menyenangkan. Bandung: PT.Remaja Rosdakarya.

Novianti, Nike, dkk. Penerapan Model Pembelajaran Inkuiri Terbimbing untuk Meningkatkan Keterampilan Proses IPA dan Hasil Belajar Siswa Kelas VIII BSMP Negeri 1 Wagir. Malang: Universitas Negeri Malang.

Rusman. 2011. Model-model Pembelajaran.Jakarta : PT. Raja Grafindo Persada. Sanjaya, Wina. 2008. Strategi Pembelajaran Berorientasi Standar Proses Pendidikan. Jakarta: Kencana Prenada Media Group.

Sudijono, Anas. 2005. Pengantar Statistik Pendidikan. Jakarta: PT. Raja Grafindo Persada.

Sudjana, Nana. 2010. Penilaian Hasil Proses Belajar Mengajar. Bandung: PT. Remaja Rosdakarya.

Sugihartono, dkk. 2007. Psikologi Pendidikan. Yogyakarta: UNY Press.

Trianto. 2010. Mendesain Model Pembelajaran Inovatif-Progresif: Konsep, Landasan, dan Implementasinya pada Kurikulum Tingkat Satuan Pendidikan (KTSP). Jakarta: Kencana Prenada Media Group.

Wardhana, Yana. 2006. Teori Belajar dan Mengajar. Bandung: PT. Pribumi Mekar. 